372 Administrative Appointments

372 New Appointments

372 Promotions
372 Awards

372 In the News

373 Books by Our

Readers

374 In Memoriam

SPOTLIGHT

\title{
Grain of Sand Award of 2009 Presented to Professors Lloyd I. Rudolph and Susanne Hoeber Rudolph
}

The Interpretive Methodologies and Methods Conference Group of the American Political Science Association is proud to announce the creation of the "Grain of Sand" Award to honor a political scientist whose contributions to interpretive studies of the political, and, indeed, to the discipline itself, its ideas, and its persons, have been longstanding and merit special recognition.

The award draws its name from the combined inspiration of the opening lines of William Blake's "Auguries of Innocence" and Wislawa Szymborska's "View with a Grain of Sand." It is intended to honor a scholar whose contributions demonstrate creative and sustained engagement with questions of enduring political importance from an interpretive perspective. Echoing Szymborska's "We call it a grain of sand," the award underscores the centrality of meaning-making in both the constitution and study of the political. Drawing on Blake's "To see a world in a grain of sand," the award honors the capacity of interpretive scholarship to embody and inspire imaginative theorizing, the intentional cultivation of new lines of sight through an expansion of literary and experiential resources, and the nourishing of a playfulness of mind that is so necessary to the vitality of social science.

We are honored that Lloyd Rudolph and Susanne Rudolph have accepted the Grain of Sand award for 2010, the first one to be given. In the view of members of the award committee, they embody the attributes described above both personally and in terms of their work. Emeriti at the University of Chicago, they began their political science careers as graduate students at Harvard. Susanne is a past president of APSA (2003-2004), as well as of the Association of Asian Studies. Their shared interest in comparative politics led them to fieldwork in India, an engagement that has continued over 40 years. Among their many publications, solo and joint, are several that engage themes close to the heart of this Conference Group.

But more than these, it was a passage in their co-authored "Writing India: A career overview" (India Review vol. 7, no. 4: 266-94), which I was recently rereading, that caught my eye as symbolic of the contributions Lloyd and Susanne have made to "the interpretive." They reflect there at one point on a comment of Vicky Hattam's deploring the "'deep and enduring' split between theory and empirical research in political science" (270), noting that that split left "'no space for the kind of work I aspire to"' (271). They experienced the same split, they write,

but not the disempowerment she experienced. Our teachers and, subsequently, colleagues at Harvard ... used theory to frame and analyze historical and empirical questions. We learned too ... that theory, social and psychological as well as political, helped to identify and answer questions.

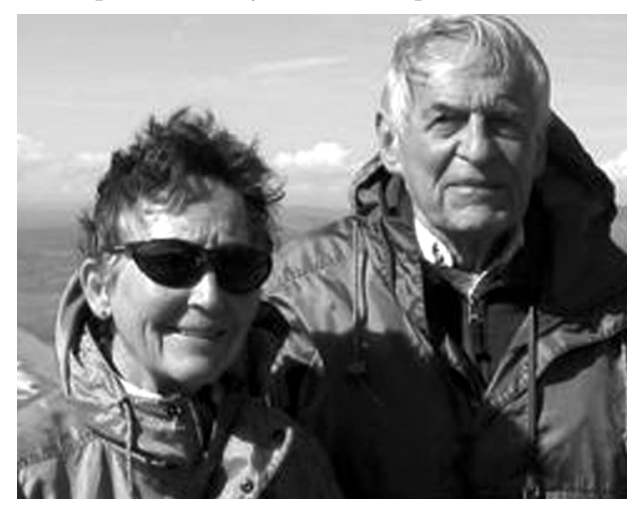

... At the University of Chicago, theory mattered. ... Like M. Jourdain in Moliere's Bourgeois Gentilhomme who was surprised to learn that he was speaking prose, we were surprised to find that we were speaking theory. (271)

It is this eclecticism-this willingness to draw on research-relevant theoretical ideas from whatever discipline and to bring those theories to bear on "the political" in their empirical material-that we applaud in recognizing Lloyd Rudolph and Susanne Rudolph with this award: they have seen political worlds in grains of sand and, moreover, have held these up for scrutiny in ways that have enabled all of us to see how it is our touch, our gaze, our narrative, that creates both grain and sand in what we study.

\section{Dvora Yanow, for the 2009 Grain of Sand} Award committee

\section{SUSANNE HOEBER RUDOLPH: REMARKS ON RECEIVING THE "GRAIN OF SAND" AWARD}

I'm happy to be the recipient of an award recognizing the work of scholars who deploy literary and experiential resources in pursuit of meaning. And I am delighted that there is a conference-related group institutionalizing this honor. On this auspicious occasion, I thought I would offer a few remarks about my current work.

During each of the 11 years Lloyd and I have spent in India, I wrote home weekly letters addressed to "Dear All"about ten letters per research year, each five or six pages long-about six hundred pages in all. I'm in the process of editing these letters.

What can I say in justification of this enterprise? What kind of communication is a "letter"? How does it fit into the work of a comparative political scientist? What is its methodological implication?

A letter is first of all a personal document, its form shaped by the persona of the writer. That was even more true before the day of the typewriter, when the persona was symbolically present in the handscript of the writer. A personal document expresses first-person knowledge, what "I know" by virtue of my experience, frankly tinged by the subjectivity of the writer. 